\title{
Indirect detection of respiratory viruses responsible for respiratory disease in sheep
}

\author{
[Detecção indireta de vírus respiratórios responsáveis pela doença respiratória ovina]
}

\section{"Artigo Científico/Scientific Article"}

\author{
Mariane Ferreira Franco ${ }^{1}$, Natália Carrillo Gaeta ${ }^{*}$, Mario Augusto Reyes Alemán ${ }^{1}$, \\ Adriana Hellmeister Campos Nogueira ${ }^{2}$, Ediviges Maristela Pituco ${ }^{2}$, \\ Mario Felipe Alvarez Balaro ${ }^{3}$, Lilian Gregory ${ }^{1}$
}

\author{
${ }^{1}$ Departamento de Clínica Médica, Faculdade de Medicina Veterinária e Zootecnia, Universidade de São \\ Paulo, São Paulo-SP, Brasil. \\ ${ }^{2}$ Laboratório de Viroses de Bovídeos, Instituto Biológico, São Paulo-SP, Brasil. \\ ${ }^{3}$ Universidade Federal Rural do Rio de Janeiro, Seropédica-RJ, Brasil. \\ *Autor para correspondência/Corresponding author: E-mail: natalia.gaeta@ hotmail.com
}

\begin{abstract}
Respiratory disease in sheep is an important disease in sheep flocks, in which viruses are categorized as primary etiological agents. It is responsible for elevated economic losses in sheep production and new data about its occurrence and the etiological agents are necessary to understand its situation in Brazilian flocks. This research aimed to detect antibodies against Bovine Viral Diarrhea Virus, Bovine Herpesvirus type 1, Bovine Respiratory Syncytial Virus (BRSV) and Bovine Parainfluenza type 3 (bPI-3) virus in healthy and pneumonic sheep in relation to clinical signs of respiratory disease. Ninety-nine male and female sheep from the states of São Paulo (SP) and Rio de Janeiro (RJ) were enrolled in this study. They were classified as healthy and pneumonic using physical examination. Serum samples were obtained, and they were used to determine the presence of antibodies against respiratory viruses using serum neutralization test. The association between the microorganisms, clinical status, and clinical signs of respiratory disease in sheep was evaluated. Antibodies against Bovine Parainfluenza type 3 virus were mainly detected (52.5\%), followed by Bovine Respiratory Syncytial Virus (48.5\%). Data analysis did not reveal any association between the presence of antibodies and clinical signs of respiratory disease in sheep. Respiratory disease is an important issue in sheep production in which different bacterial and viral etiologic agents may be involved in its development. BRSV and bPI-3 are circulating in sheep flocks from São Paulo and Rio de Janeiro.
\end{abstract}

Keywords: bovine herpesvirus type-1; parainfluenza type -3 ; bovine respiratory syncytial virus; bovine viral diarrhea virus; serology.

\section{Resumo}

A doença respiratória dos ovinos é uma doença importante em rebanhos ovinos, na qual os vírus são categorizados como agentes etiológicos primários. É responsável por perdas econômicas elevadas na produção de ovinos e novos dados sobre sua ocorrência e os agentes etiológicos são necessários para compreender sua situação em rebanhos brasileiros. Esta pesquisa teve como objetivo detectar anticorpos contra o vírus da Diarreia Viral Bovina, Herpesvírus Bovino tipo 1, Vírus Respiratório Sincicial Bovino (BRSV) e Parainfluenza Bovina tipo 3 (bPI-3) em ovelhas saudáveis e pneumônicas apresentando manifestações clínicas de doença respiratória. Noventa e nove ovelhas machos e fêmeas dos Estados de São Paulo (SP) e do Rio de Janeiro (RJ) foram incluídas neste estudo. Eles foram classificados como saudáveis e pneumônicos pelo exame físico. Amostras de soro foram obtidas e utilizadas para determinar a presença de anticorpos contra os vírus respiratórios por meio do teste de soro neutralização. A associação entre os achados sorológicos, estado clínico e manifestações clínicas da doença respiratória dos ovinos foi avaliada. Anticorpos contra o vírus Parainfluenza bovina tipo 3 foram os mais detectados (52,5\%), seguido pelo Vírus Respiratório Sincicial Bovino (48,5\%). A 
análise dos dados não revelou associação entre a presença de anticorpos e manifestações clínicas de doença respiratória em ovinos. A doença respiratória é uma questão importante na produção de ovinos, na qual diferentes agentes bacterianos e virais podem estar envolvidos em seu desenvolvimento. BRSV e bPI-3 estão presentes ovinos de São Paulo e no Rio de Janeiro.

Palavras-chave: herpesvírus bovino tipo 1; parainfluenza tipo 3; vírus respiratório sincicial bovino; vírus da diarreia viral bovina; sorologia.

\section{Introduction}

Ovine respiratory disease is responsible for high economic losses in sheep production (Martin, 1996) and it is the main cause of death in sheep farms (Lacasta et al., 2008). Intensive management, age, gender, breed, failure of passive immunity transfer, transportation, weaning, dehorning, and climate are important predisposing factors associated with the disease (Lacasta et al., 2008; Mahdi et al., 2015; Navarro et al., 2019).

Viruses are primary agents of respiratory disease in sheep. These microorganisms produce cytokines, changing the respiratory environment and immune cell function (Bosch et al., 2013). Bovine Viral Diarrhea Virus, Bovine Herpesvirus type 1, Bovine Respiratory Syncytial Virus and Parainfluenza virus type 3 are commonly agents of ovine respiratory disease (Sharp and Nettleton, 2007).

Bovine respiratory syncytial virus (BRSV) belongs to the Family Paramyxoviridae (ICTV, 2014). It is an important etiological agent of bovine respiratory disease, and it is often related to increased risk of secondary infection in sheep, commonly caused by bacteria (Belknap, 2005). Clinical signs of BRSV infection include anorexia, conjunctivitis, cough, fever, serous nasal discharge, increased respiratory and heart rates, and crackles on pulmonary auscultation (Martin, 1996; Belknap, 2005; Caswell and Williams, 2007; Gonçalves, 2014).

Bovine Herpesvirus Type 1 (BoHV-1) belongs to the Family Herpesviridae, Genus Varicellovirus (ICTV, 2014). BoHV-1 is an etiologic agent of the bovine respiratory disease, but it is also important to the ovine disease (Trueblood et al., 1978). Antibodies against BoHV-1 have been detected in small ruminants in several countries, suggesting that hosts other than cattle may contribute to the spread of infection (Maiga and Sarr, 1992; Suresh and Suribabu, 1993; Tiwari et al., 2016).

Bovine Viral Diarrhea Virus (BVDV) belongs to the Family Flaviviridae, Genus
Pestivirus (ICTV, 2014). Although cattle is the main host, goat, swine, rabbit, and buffalo can be infected and show clinical signs (Radostits et al., 2002). Sheep may also be susceptible to natural and experimental infections (Loken, 1995). Pregnant ewe inoculated with BVDV showed several clinical signs including fever, nasal discharge, anorexia, apathy and diarrhea (Potgieter, 2004). BVDV infection in Brazilian sheep was described in the States of Rio Grande do Sul (Pescador et al., 2004) and Pernambuco (Silva et al., 2016).

Bovine Parainfluenza type 3 virus (boPI-3) belongs to the Family Paramyxoviridae and Genus Paramyxovirus (ICTV, 2014). Parainfluenza virus destroys epithelial cells, decreases mucociliary clearance, and decreases the number of neutrophils and macrophages (Bryson et al., 1983; Slauson et al., 1987; Brown and Ananaba, 1988; Willoughby et al., 1992). Infections are mainly subclinical or moderate, but high mortality is observed during sporadic outbreaks. Infected animals usually show fever, cough, tachypnea, apathy, anorexia, and excessive nasal discharge (Sharp and Nettleton, 2007). Bovine Parainfluenza type 3 virus is distributed worldwide (Cabello and Rivera, 2006; Jehan, 2009; Rusenova, 2009; Saeed et al., 2016), including in Brazilian sheep flocks (Dal Pizzol et al., 1986; Gonçalves et al., 2011; Contreras-Luna et al., 2017).

Ovine respiratory diseases are poorly studied in Brazil. New data on its occurrence and etiological agents are necessary to understand the current epidemiological situation in Brazilian flocks. Thus, the aim of this cross-sectional study was to detect antibodies against bovine viral diarrhea virus, bovine herpesvirus type 1 , and bovine respiratory syncytial virus in healthy and sheep showing clinical signs of respiratory disease.

\section{Material and Methods}

The present research was conducted at the Laboratory of Bovine Viruses, Biological Institute, and at the Department of Internal Medicine, School 
of Veterinary Medicine and Animal Science, University of São Paulo, Brazil.

\section{Animals and case definition}

Ninety-nine male and female sheep, one month to seven years old from 12 sheep flocks from São Paulo (N=06) and Rio de Janeiro (N=06) were enrolled in this cross-sectional study, according to a non-probabilistic convenience sampling. Animals were from intensive and semi-intensive farms, some of which also had cattle and/or goats. No vaccination for respiratory viruses was performed in any herd. All sheep were in a pen before the physical examination, allowing the veterinarians to observe their behavior and perform physical examination. Animals were separated in two groups (healthy and pneumonic) after physical examination performed by two veterinarians of our research group with experience in small ruminant internal medicine. Vital parameters (heart and respiratory rates and rectal temperature), consciousness level, color of mucosa, level of hydration, and cough were assessed. Specific examination of the respiratory tract was also performed: presence of mucopurulent/purulent nasal discharge, altered sounds on thoracic percussion, and thoracic auscultation. Sheep were considered pneumonic if showing at least two of the following parameters: cough, rectal temperature higher than $40^{\circ} \mathrm{C}$, respiratory rate higher than 30 respiratory movements per minute, and altered sounds on thoracic auscultation (Benesi et al., 2013; Gaeta et al., 2018a).

\section{Sampling}

Eight milliliters of blood were obtained from both healthy and pneumonic sheep from the jugular vein using a dry vacutainer tube $(B D$, New Jersey, USA). Samples were centrifuged at $600 \times \mathrm{g}$ for 15 minutes and serum was stored at $-20^{\circ} \mathrm{C}$.

\section{Serological tests}

Serum neutralization test was performed to detect antibodies against BVDV (ac-BVDV) (OIE, 2014a), BoHV-1 (ac-BoHV-1) (OIE, 2014b), BRSV (ac-BRSV) (Affonso, 2010) and bPI-3 (acbPI-3v) (USDA, 2005). Serological response to these respiratory viruses was evaluated in relation to BVDV-Ia NADL strain, BoHV-1 Los Angeles strain, BRSV ATCC VR-1485 and PI-3v ATCC VR 281. Viruses and samples were incubated in Madin-Darby Bovine Kidney cells (MDBK) in 96 well plates, which were analyzed after incubation at $37^{\circ} \mathrm{C} / 5 \% \mathrm{CO}$. Antibody titers were expressed as the inverse of the dilution where the lack of cytopathic effect was observed. Samples showing titer equal or higher than three were considered reactive. Laboratory personnel were blinded to sheep health status during the tests.

\section{Statistical analysis}

The association between serology results and health status, clinical signs and severity of sheep respiratory disease was calculated using Chisquare test or Fisher's Exact test. Variables with a $\mathrm{P}$-value $<0.05$ were considered significant. All calculations were performed using Software Statistical Package for Social Sciences 25.0 (SPSS, IBM).

\section{Results}

Following physical examination, sheep were classified as healthy $(67.7 \%$; 67/99) or pneumonic $(32.3 \%$; 32/99) sheep. According to the region evaluated, ill sheep were detected in São Paulo (28\%; 09/32) and Rio de Janeiro (71.8\%; 23/32).

Antibodies against BRSV (ac-BRSV) and boPI-3 (ac-boPI-3) were detected in 48.5\% (48/99) and $52.5 \%(52 / 99)$, respectively. In relation to clinical status, ac-BRSV were numerically higher in pneumonic sheep $(\mathrm{P}=0.39)$. On the other hand, healthy sheep showed numerically more ac-bPI-3v compared to pneumonic sheep $(\mathrm{P}=0.28)$ (Table 1). Co-infection were detected in both healthy $(29.8 \%$; 20/67) and ill sheep (28.1\%; 09/32) ( $\mathrm{P}=0.860)$. Ac-BVDV and ac-BoHV-1 were not detected.

Antibody titers ranged from $0.3-1.8$ for BRSV and from 0.3-2.7 for boPI-3v. According to health status, BRSV titers ranging from 1.2-1.8 were more frequent in healthy sheep $(\mathrm{P}>0.05)$, whereas $\mathrm{bPI}-3 \mathrm{v}$ titers ranging from 1.8-2.7 were more detected in pneumonic sheep $(\mathrm{P}>0.05)$ (Table 2).

Data analysis did not reveal any association between the presence of antibodies and clinical signs of respiratory disease in sheep (Table 3). In addition, no differences were detected according to the severity of the disease (Table 4).

\section{Discussion}

Respiratory diseases of ruminants are multifactorial including several etiological agents and predisposing factors. Once established in the respiratory mucosa, viruses are responsible for changing the respiratory environment (especially the mucociliary system), production of cytokines, 
and decrease in immune cell activity (Bosch et al., 2013). These issues enhance the risk of secondary bacterial infections (Hartel et al., 2004; Autio et al.,
2007). Therefore, viral infections might be considered as both determining and predisposing factors to respiratory disease.

Table 1. Antibodies against BRSV and boPI-3 according to health status (healthy and pneumonic) of sheep from São Paulo and Rio de Janeiro, Brazil, 2018.

\begin{tabular}{lccc}
\hline \multirow{2}{*}{ Antibodies } & \multicolumn{2}{c}{ Health Status } & \multirow{2}{*}{ P-value CI (95\%) } \\
\cline { 2 - 3 } & Healthy \%(N) & Pneumonic \%(N) & \\
\hline BRSV & & & $0.39(0.67-3.70)$ \\
Absent & $55.2(37 / 67)$ & $56.8(14 / 32)$ & \\
Present & $44.8(30 / 67)$ & & \\
& & & \\
boPI-3v & & $56.3(18 / 32)$ & $0.28(0.25-1.38)$ \\
Absent & $43.3(29 / 67)$ & $43.8(14 / 32)$ & \\
Present & $56.7(38 / 67)$ & & \\
\hline
\end{tabular}

BRSV: Bovine Respiratory Syncytial Virus; boPI-3: Bovine Parainfluenza type-3

Table 2. Antibody titers of BRSV and BoPI-3 according to health status (healthy and pneumonic) of sheep from São Paulo and Rio de Janeiro, Brazil, 2017.

\begin{tabular}{lcccc}
\multicolumn{1}{c}{ Antibody Titer } & Healthy \%(N) & Pneumonic \%(N) & Total \%(N) & P-value CI (95\%) \\
\hline BRSV & & & & \\
$0.3-0.9$ & $90.0(27 / 30)$ & $94.4(17 / 18)$ & $91.7(44 / 48)$ & 1.00 \\
$1.2-1.8$ & $10.0(03 / 30)$ & $05.6(01 / 18)$ & $08.3(04 / 48)$ & $(0.051-5.513)$ \\
boPI-3v & & & & \\
$0.3-1.5$ & $71.1(27 / 38)$ & $64.3(09 / 14)$ & $68.3(36 / 52)$ & 0.738 \\
$1.8-2.7$ & $28.9(11 / 38)$ & $35.7(05 / 14)$ & $30.8(16 / 52)$ & $(0.372-4.997)$ \\
\hline
\end{tabular}

BRSV: Bovine Respiratory Syncytial Virus; boPI-3: Bovine Parainfluenza type-3

Table 3. Antibodies against BRSV and boPI-3 according to clinical signs of respiratory disease in sheep during physical examination, Brazil, 2018.

\begin{tabular}{|c|c|c|c|c|c|c|}
\hline \multirow{3}{*}{ Clinical signs } & \multicolumn{5}{|c|}{ Antibodies } & \multirow[b]{3}{*}{$\begin{array}{c}\text { P-value } \\
\text { (IC95\%) }\end{array}$} \\
\hline & \multicolumn{2}{|c|}{ BRSV } & \multirow[b]{2}{*}{$\begin{array}{l}\text { P-value } \\
\text { (IC95\%) }\end{array}$} & \multicolumn{2}{|c|}{ boPI-3 } & \\
\hline & $\begin{array}{c}\text { Absent } \\
\%(\mathrm{~N})\end{array}$ & $\begin{array}{c}\text { Present } \\
\%(N)\end{array}$ & & $\begin{array}{c}\text { Absent } \\
\%(\mathrm{~N})\end{array}$ & $\begin{array}{c}\text { Present } \\
\%(\mathrm{~N})\end{array}$ & \\
\hline \multicolumn{7}{|l|}{ RR (rmpm) } \\
\hline$<30$ & $54.9(28 / 51)$ & $41.7(20 / 48)$ & 0.22 & $51.1(24 / 47)$ & $46.2(24 / 52)$ & 0.68 \\
\hline$>\mathbf{3 0}$ & $45.1(23 / 51)$ & $58.3(28 / 48)$ & $(0.76-3.77)$ & $48.9(23 / 47)$ & $53.8(28 / 52)$ & $(0.55-2.68)$ \\
\hline \multicolumn{7}{|l|}{ Auscultation } \\
\hline Normal & $62.7(32 / 51)$ & $62.5(30 / 48)$ & 1.00 & $66.0(31 / 47)$ & $59.6(31 / 52)$ & 0.54 \\
\hline Abnormal & $37.3(19 / 51)$ & $37.5(18 / 48)$ & $(0.44-2.82)$ & $34.0(16 / 47)$ & $40.4(21 / 52)$ & $(0.57-2.97)$ \\
\hline \multicolumn{7}{|l|}{ Percussion } \\
\hline Normal & $62.7(32 / 51)$ & $60.4(29 / 48)$ & 0.83 & $66.0(31 / 47)$ & $57.7(30 / 52)$ & 0.41 \\
\hline Abnormal & $37.3(19 / 51)$ & $39.6(19 / 48)$ & $(0.49-2.48)$ & $34.0(16 / 47)$ & $42.3(30 / 52)$ & $(0.62-3.21)$ \\
\hline \multicolumn{7}{|l|}{ Cough } \\
\hline Absent & $90.2(46 / 51)$ & $89.6(43 / 48)$ & 1.00 & $85.1(40 / 47)$ & $94.2(49 / 52)$ & 0.18 \\
\hline Present & $09.8(05 / 51)$ & $10.4(05 / 48)$ & $(0.28-3.95)$ & $14.9(07 / 47)$ & $05.8(03 / 52)$ & $(0.08-1.44)$ \\
\hline \multicolumn{7}{|l|}{ Rectal $\mathbf{T}^{\mathbf{O}}$} \\
\hline$<40^{\circ} \mathrm{C}$ & $96.1(49 / 51)$ & $97.9(47 / 48)$ & 0.52 & $93.6(44 / 47)$ & $100(52 / 52)$ & 0.10 \\
\hline$>40^{\circ} \mathrm{C}$ & $03.9(02 / 51)$ & $02.1(01 / 48)$ & $(0.46-5.94)$ & $06.4(03 / 47)$ & $00(00 / 52)$ & $(-)$ \\
\hline
\end{tabular}


Table 4. Antibodies against BRSV and boPI-3 according to severity of the respiratory disease in sheep, Brazil, 2018.

\begin{tabular}{|c|c|c|c|c|c|c|}
\hline \multirow{3}{*}{ Severity } & \multicolumn{6}{|c|}{ Antibodies } \\
\hline & \multicolumn{2}{|c|}{ BRSV } & $\begin{array}{l}\text { P-value } \\
\text { (IC95\%) }\end{array}$ & \multicolumn{2}{|c|}{ boPI-3 } & $\begin{array}{l}\text { P-value } \\
\text { (IC95\%) }\end{array}$ \\
\hline & $\begin{array}{c}\text { Absent } \\
\%(\mathrm{~N})\end{array}$ & $\begin{array}{c}\text { Present } \\
\%(\mathrm{~N})\end{array}$ & 1.00 & $\begin{array}{c}\text { Absent } \\
\%(\mathrm{~N})\end{array}$ & $\begin{array}{c}\text { Present } \\
\%(\mathrm{~N})\end{array}$ & 0.71 \\
\hline Moderate & $64.3(09 / 14)$ & $61.1(11 / 18)$ & $(0.27-4.86)$ & $66.7(12 / 18)$ & $57.1(08 / 14)$ & $(0.35-6.34)$ \\
\hline Severe & $35.7(05 / 14)$ & $38.9(07 / 18)$ & & $33.3(06 / 18)$ & $42.9(06 / 14)$ & \\
\hline
\end{tabular}

BRSV: Bovine Respiratory Syncytial Virus; boPI-3: Bovine Parainfluenza type 3; Moderate: two clinical signs of respiratory disease; Severe: more than two clinical signs of respiratory disease.

Bovine Parainfluenza type 3 virus is the main cause of viral respiratory disease in sheep, and the main isolated virus from natural occurrence of the disease (Martin, 1996; Sharp and Nettleton, 2007; Gafer et al., 2009; Rusenova, 2009). Our results are similar to several Brazilian researches that also described its increased occurrence in sheep flocks (Dal Pizzol et al., 1989; Gonçalves et al., 2011). Bovine Respiratory Syncytial virus has a tropism for respiratory tissue (Van der Poel et al., 1994) and it is a well-known pathogen of bovine respiratory disease (Valarcher and Taylor, 2007). Bovine Respiratory Syncytial virus infection in sheep was also described in Mexico (ContrerasLuna et al., 2017), Peru (Cabello and Rivera, 2006), and Brazil (Gonçalves et al., 2011). As stated in the present research, Marcondes (2010) also detected an increased frequency of ac-BRSV in pneumonic sheep.

To the best of our knowledge, this is the first research that attempted to evaluate the association between viral infection and clinical signs of respiratory disease in sheep. Antibodies against BRSV has been associated with unilateral airflow and serous nasal discharge, and tendencies were observed between ac-BoHV-1 and rectal temperature and breathing pattern in dairy cattle (Gaeta et al., 2018). However, no association was detected in the present study. Discrepancies in researches may be due to different locations, species, management, production type, and age (Silva et al., 2016). Further studies are necessary to obtain a presumptive diagnosis of the microorganism based on clinical signs.

Antibodies against respiratory viruses in the healthy group may be related to old infection and immunological memory. Co-infection (particularly virus and bacteria) may be the cause of antibodies in the sick group. In addition, viral infection has a fast course and predisposes to secondary infections that worsen the pneumonia. Sheep respiratory disease is a complex illness in which different pathogens may be responsible for the disease (alone or co-infection) (Navarro et al., 2019).
Determining its real cause is a challenge for the veterinarians. Clinical, microbiological, and pathological diagnosis and epidemiological information are mandatory during the investigation of this disease.

\section{Conclusion}

Respiratory disease is an important issue in sheep production in which different bacterial and viral etiologic agents might be involved in its development. Bovine Respiratory Syncytial virus and Bovine Parainfluenza type 3 virus are present in sheep flocks in the states of São Paulo and Rio de Janeiro.

\section{Conflict of Interest}

The authors declare no conflict of interest.

\section{Ethics Committee}

All procedures were carried out in agreement with the Ethics Committee on the Use of Animals in Experimentation, FMVZ-USP (Protocol n. 3498060716).

\section{Acknowledgements}

Authors are grateful to all participants and The Brazilian National Council for Scientific and Technological Development for the financial support.

\section{References}

Affonso, I.B.; Gatti, S.P.; Alexandrino, B.; Oliveira, M.C.; Medeiros, A.S.R.; Buzinaro, M.G.; Samara, S.I. Detection of antibodies against bovine respiratory syncytial virus (BRSV) in dairy cattle with different prevalences of bovine herpesvirus type-1 (BoHV-1) in São Paulo State, Brazil. Semina: Ciências Agrárias, 32(1): 295-299, 2011.

Autio, T.; Pohjanvirta, T.; Holopainen, R.; Rikula, U.; Pentikainen, J.; Huovilainen, A.; Rusanen, H.; Soveri, T.; Sihvonen, L.; Pelkonen, S. Etiology of respiratory disease in nonvaccinated, non-medicated calves in 
rearing herds. Veterinary Microbiology, 119: 256-265, 2007.

Belknap, E.B. Enfermidades do sistema respiratório. In: Pugh, D.G. (Ed). Clínica de ovinos e caprinos. $1^{\text {a }}$ ed. São Paulo: Roca, 2005. p. 119-138.

Benesi, F.J.; Bertagnon, H.G.; Wachholz, L.; Leal, M.L.R.; Fernandes, W.R.; Benites, N.R.; Melville, P. Microbiota bacteriana e citologia da região traqueobrônquica de bezerros no período neonatal. Pesquisa Veterinária Brasileira, 33(6): 700-704, 2013.

Bosch, A.A.T.M.; Biesbroek, G.; Trzcinski, K.; Sanders, E.A.M.; Bogaert, D. Viral and bacterial interactions in the upper respiratory tract. PLos Pathogens, 49(1): e1003057, 2013.

Brown, T.T.; Ananaba, G. Effect of respiratory infections caused by bovine herpesvirus-1 or parainfluenza-3 virus on bovine alveolar macrophage functions. American Journal of Veterinary Research, 49(9): 1447-1451, 1988.

Bryson, D.G.; McNulty, M.S.; McCracken, R.M.; Cush, P.F. Ultrastructural features of experimental parainfluenza type 3 virus pneumonia in calves. Journal of Comparative Pathology, 93(3): 397-414, 1983.

Cabello, R.K.; Rivera, G. Frecuencia de los virus parainfluenza-3, respiratorio sincitial y diarrea viral bovina en un rebaño mixto de una comunidad campesina de Cusco. Revista de Investigaciones Veterinárias de Perú, 17(2): 167-172, 2006.

Caswell, J.L.; Williams, K. The respiratory system. In: Jubb, K.V.F.; Kennedy, P.C.; Palmer, N. (Ed.). Pathology of domestic animals. Edinburgh: Saunders Elsevier, 2007. p. 594622.

Contreras-Luna, M.J.; Ramírez-Martínez, L.A.; Sarmiento Silva, R.E.; Cruz Lazo, C.; Pérez Torres, A.; Sánchez-Betancourt, J.I. Evidence of respiratory syncytial virus and parainfluenza-3 virus in Mexican sheep. Virus Disease, 28(1): 102-110, 2017.

Dal Pizzol, M.; Ravazzolo, A.P.; Fernandes, J.C.T.; Moojen, V. Detecção de anticorpos para o vírus Parainfluenza tipo 3 em bovinos e ovinos no Rio Grande do Sul, Brasil. Arquivos da Faculdade de Veterinária da UFRGS, 17: 59-64, 1989.
Gaeta, N.C.; Ribeiro, B.L.M.; Alemán, M.A.R.; Yoshihara, E.; Nassar, A.F.C.; Marques, E.C.; Timenetsky, J.; Gregory, L. Bacterial pathogens of the lower respiratory tract of calves from Brazilian rural settlement herds and their association with clinical signs of bovine respiratory disease. Pesquisa Veterinária Brasileira, 38(3): 374-381, 2018a.

Gaeta, N.C.; Ribeiro, B.L.M.; Alemán, M.A.R.; Yoshihara, E.; Marques, E.C.; Hellmeister, A.N.; Pituco, E.M.; Gregory, L. Serological investigation of antibodies against respiratory viruses in calves from Brazilian family farming and their relation to clinical signs of bovine respiratory disease. Pesquisa Veterinária Brasileira, 38(4): 642-648, 2018b.

Gonçalves, R.C. Semiologia do Sistema respiratório. In: Feitosa, F.L.F. Vete (Ed.). Semiologia veterinária: a arte do diagnóstico. $3^{\mathrm{a}}$ ed. São Paulo: Roca, 2014. p.313-331.

Gonçalves, R.C.; Silva, A.A.; Ferreira, D. Detection of serum antibodies to parainfluenza type 3 virus, respiratory syncytial virus, bovine viral diarrhea virus, and herpes virus type 1 in sheep in the Region of Botucatu, São Paulo. Brazilian Journal of Veterinary Medicine and Animal Health, 3(4): 1-5, 2011.

International Committee on Taxonomy of Viruses (ICTV). 2014. Available at: <https://talk.ictvonline.org/>. Accessed on: 10 jul. 2019.

Jehan, A.M. Isolation and Characterization of PI-3 Virus from Sheep and Goats. International Journal of Virology, 5(1): 28-35, 2009.

Lacasta, D.; Ferrer, L.M.; Ramos, J.J.; González, J.M.; De las Heras, M. Influence of climatic factors on the development of pneumonia in lambs. Small Ruminant Research, 80: 1-3, 2008.

Loken, T. Border disease in sheep. Veterinary Clinics of North America, 11: 579-595, 1995.

Mahdi, A.; Assel, A.; Haddel, B. A study of some pathological lesions in the lung of sheep in Duhok Abattoir. Journal of Veterinary Research, 14(2): 265-277, 2015.

Maiga, S.; Sarr, J. Epidemiological survey of the main respiratory viruses of small ruminants in 
Mali. Revenue D'Elevage et de Medicine Veterinarie Pays Tropicale, 45: 15-17, 1992. Marcondes, J.S. Pesquisa de vírus relacionados com doenças respiratórias em ovinos sadios e naturalmente acometidos. $116 \mathrm{p}$. Tese (Doutorado) - Faculdade de Medicina Veterinária e Zootecnia, campus Botucatu, Universidade Estadual Paulista, 2010.

Martin, W.B. Respiratory infections of sheep. Comparative Immunology Microbial Infectious Disease, 19(3): 171-179, 1996.

Navarro, T.; Ramos, J.J.; Ruíz de Arcaute, M.; González, J.M. Predisposing factors inducing ovine respiratory complex in intensive-reared lambs. Small Ruminant Research, 180: 106111, 2019.

Pescador, C.A.; Corbellini, L.G.; Driemeier, D.; Gonçalves, R.K.; Cruz, C. Neurological disorder associated with Pestivirus infection in sheep in Rio Grande do Sul, Brazil. Ciência Rural, 34(3): 935-938, 2004.

Potgieter, L. Bovine viral diarrhea and mucosal disease. In: Coetzer, J.; Thomsom, N.G.R.; Tustin, R. (Ed.). Infectious diseases of livestock. $2^{\text {nd }}$ ed. Cape Town: Oxford University Press, 2004. p. 946-969.

Radostits, O.M.; Blood, D.C.; Gay, C.C. Clínica Veterinária: um tratado de doenças dos bovinos, ovinos, suínos, caprinos e equinos. $9^{a}$ ed. Rio de Janeiro: Guanabara Koogan, 2002.

Rusenova, N. Comparison of the seroprevalence against some respiratory viruses in mixed sheep-goat herds in two regions of Bulgaria. Trakia Journal of Science, 7(4): 58-62, 2009.

Saeed, K.I.; Ali, Y.H.; Taha, K.M.; Mohammed, N.E.; Nouri, M.N.; Mohammed, B.A.; Mohammed, O.I.; Elmagboul, S.B.; AlGhazali, F.A. Para influenza virus 3 infection in cattle and small ruminants in Sudan. Journal of Advances in Veterinary Animal Research, 3(3): 236, 2016.

Sharp, J.M.; Nettleton, P. Acute respiratory virus infections. In: Aitken, I. (Ed.). Diseases of sheep. $4^{\text {th }}$ ed. Iowa: Blackwell Publishing Professional, 2007. p. 207-209.

Silva, T.L.A.; Oliveira, M.M.M.; Teixeira, M.N.; Mota, I.O.; Castro, R. Anticorpos anti pestivírus em caprinos e ovinos do sertão do estado de Pernambuco, Brasil. PUBVET, 10(2): 132-137, 2016.

Slauson, D.O.; Lay, J.C.; Castleman, W.L.; Neilsen, N.R. Alveolar macrophage phagocytic kinetics following pulmonary parainfluenza-3 virus infection. Journal of Leukocyte Biology, 41(5): 412-420, 1987.

Suresh, P.; Suribabu, T. Serological survey of bovine herpesvirus 1 (BHV-1) in sheep in Andha Pradesh. Indian Journal of Animal Science, 63: 146-147, 1993.

Tiwari, K.; Manning, S.H.; Meyer, K.; Ponce, C.; Deallie, C.; Thomas, D.; Sharma, R. Seroprevalence of antibodies to bovine herpes virus type-1 (BoHV-1) in ruminants of Grenada, West Indies. Journal of Animal Research, 6(6): 939-942, 2016.

Trueblood, M.S.; Swift, B.L.; MchollandRaymond, L. A bovine herpesvirus isolated from sheep. Canadian Journal of Comparative Medicine, 42(1): 97-99, 1978.

UNITED STATES DEPARTMENT OF AGRICULTURE (USDA). Code of Federal Regulation, Animal and plant health inspection service, title 9: Animals and animal products. Available at: $<$ https://gov.ecfr.io/cgi-

bin/retrieveECFR?gp $=\&$ SID $=73970 \mathrm{e} 074 \mathrm{cf} 83$ 7bbda6af301a8dab4b2 \& pitd $=20180101 \& \mathrm{n}=\mathrm{p}$ t9.1.113\&r=PART\&ty=HTML\#se9.1.113_13 09>. Accessed on: 10 jul. 2019.

Willoughby, R.; McKee, S.; Riddolls, L.; Vernaillen, C.; Dubovi, E.; Lein, D.; Mahony, J.B.; Chernesky, M.; Nagy, E. The effects of equine rhinovirus, influenza virus and herpesvirus infection on tracheal clearance rate in horses. Canadian Journal of Veterinary Research, 56(2): 115-121, 1992. 